\title{
Inheritance of immunity in mice to challenge infection with Nematospiroides dubius
}

\author{
P. J. Brindley,* S. He, P. Sitepu, \\ W. A. Pattie $†$ and C. Dobson
}

\author{
Departments of Parasitology, and \\ Animal Production, $\dagger$ University of Queensland, \\ St. Lucia, 4067 Brisbane, Australia.
}

Two lines of mice (Mus musculus) were selectively reared over 10 generations for high (H) and low (L) levels of immune response to Nematospiroides dubius, an enteric nematode parasite. Filial and backcross families were derived from the two parent lines. The mode of inheritance of the trait, immune response to challenge infection with $N$. dubius, was analysed by comparing the levels of infection in the parental, filial and backcross (BC) families of mice.

The immunity of the $F_{1}$ mice was found to be dissimilar to both parents, but was closer to the $H$ value than to the level of immunity in the $L$ mice. The backcross to $H$ progeny showed levels of immunity approaching that of the $H$ mice, whereas only two of four backcross to $\mathbf{L}$ families were low immune responders. Analysis of these results indicated that the inheritance of immunity in these mice to challenge infection with $\boldsymbol{N}$. dubius was quantitative, partially dominant for high immune response, and additive, in nature.

\section{INTRODUCTION}

Several recent reviews have outlined current knowledge of the genetic factors influencing the interaction of animal parasites with the mammalian immune system (Wakelin, 1978; Mitchell, 1979; Skamene, Kongshavn and Landy, 1980; Vadas, 1980; Sher and Scott, 1982). The genetic analysis of, and the selection of economically valuable species for, resistance to disease have long been recognised as beneficial in agriculture (see Day, 1974; Falconer, 1981). Parasites, particularly helminths, compound the analysis of host immunity to infection because they evade or suppress host immune responses and because they show considerable genetical variety themselves.

Mammalian reactions to various antigens involve control by the immune response (IR) genes and the major histocompatibility locus (MHC) of genes (Benacerraf and McDevitt, 1972; Biozzi, Stiffel, Mouton, Bouthillier and Decreuesefond, 1971; Wassom, David and Gleich, 1979; Klein, Juretic, Baxevanis and Nagz, 1981) which may explain intraspecific variation in susceptibility to

\footnotetext{
* Present address: Laboratory of Parasitic Diseases, Bldg. 5, Rm. 112, National Institute of Allergy and Infectious Diseases, National Institutes of Health, Bethesda, Maryland, 20892 U.S.A.
}

parasites (Vadas, 1980; Wakelin, 1984). Sher and Scott (1982) consider that these genes might influence resistance to infection by regulating biochemical events involved in the physiological adaptation of parasites to the host environment.

In this paper we describe levels of immunity in families of mice derived from crosses and backcrosses between two lines which were selectively reared over 10 generations for high $(\mathrm{H})$ and low (L) levels of immunity to Nematospiroides dubius (=Heligmosomoides polygyrus), (Sitepu, Brindley and Dobson, 1986). N. dubius is a trichostrongyloid nematode which parasitises various rodents. The third-stage larva, which is infective for mice, is ingested. It then moults and penetrates the intestinal mucosa. The dioecious adults emerge from the gut wall one week after infection, matu re, copulate and shed eggs within the faeces of the host (see Bryant, 1973).

\section{MATERIALS AND METHODS}

\section{Mice}

High (H) and low (L) immune responder lines of mice, in terms of immune response to a challenge infection with Nemaiospiroides dubius, were selectively reared from a foundation, outbreeding 
population of Mus musculus. We have described this selection process in detail elsewhere (Sitepu and Dobson, 1982; Sitepu, et al., 1986). Briefly, $F_{1}$ progeny from crosses between outbred Quackenbush (Q) strain mice and wild caught mice were infected with $N$. dubius and the mice with the highest and lowest levels of infection were selected in a two-way experiment. At the third generation of selection, and onwards, the $\mathrm{H}$ and $\mathrm{L}$ lines of mice showed a difference in their immunity to the nematode infection and this difference expanded with subsequent selection.

First filial, $\mathrm{F}_{2}$ and backcross $(\mathrm{BC})$ mice were derived from cross-matings between $\mathrm{H}$ and $\mathrm{L}$ mice from the eighth or ninth selection generations. Specifically, a series of hybrid combinations were bred, as listed below, in order to investigate the mechanism of inheritance of immunity in mice to infection with $N$. dubius, including the influence of the sex of the parents on the immune status of their progeny. The parent lines, $\mathrm{H}$ and $\mathrm{L}$, were "inbred" at the same time as the filial and backcross mice were reared, and the progeny so derived -9 th and 10th generation $\mathrm{H}$ and $\mathrm{L}$ micewere also examined in this experiment. It is the mean number of eggs per gm (epg) for these $\mathrm{H}$ and $L$ progenies, not those for the parents of these, and the filial and the backcross progenies, which are given in the tables and figures in this paper, alongside values for the filial and backcross mice. The symbolism for the filial and backcross progeries, with the female parent given first, is as follows:

$$
\begin{aligned}
\mathrm{H} \times \mathrm{L} & =\mathrm{F}_{1} \mathrm{H} \\
\mathrm{L} \times \mathrm{H} & =\mathrm{F}_{1} \mathrm{~L} \\
\mathrm{~F}_{1} \mathrm{H} \times \mathrm{H} & =\mathrm{BC} 1 \\
\mathrm{H} \times \mathrm{F}_{1} \mathrm{H} & =\mathrm{BC} 2 \\
\mathrm{~F}_{1} \mathrm{~L} \times \mathrm{H} & =\mathrm{BC} 3 \\
\mathrm{H} \times \mathrm{F}_{1} \mathrm{~L} & =\mathrm{BC} 4 \\
\mathrm{~L} \times \mathrm{F}_{1} \mathrm{H} & =\mathrm{BC} 5 \\
\mathrm{~F}_{1} \mathrm{H} \times \mathrm{L} & =\mathrm{BC} 6 \\
\mathrm{~L} \times \mathrm{F}_{1} \mathrm{~L} & =\mathrm{BC} 7 \\
\mathrm{~F}_{1} \mathrm{~L} \times \mathrm{L} & =\mathrm{BC} 8 \\
\mathrm{~F}_{1} \mathrm{H} \times \mathrm{F}_{1} \mathrm{~L} & =\mathrm{F}_{2} .
\end{aligned}
$$

\section{Parasite}

$N$. dubius was maintained in our laboratory in outbred Quackenbush strain mice. Third-stage lar- vae were harvested by irrigating cultures of infected faeces comminuted with tap water, streaked onto moist filter paper and incubated for 1 week at $26^{\circ}$ (Dobson and Owen, 1977). Larvae were stored in a shallow layer of tap water at $4^{\circ}$ for 4 weeks prior to innoculation into experimental mice.

\section{Assessing the phenotype}

Experimental mice were infected when 7 to 8 weeks old with 100 infective larvae by gastric gavage. Three weeks later they were drenched free of $N$. dubius infection with an anthelmintic $\left(20 \mathrm{mg} \mathrm{kg}^{-1}\right.$ levamisole phosphate, "Nilverm", ICI, Australia), also by gastric gavage. Four days later the mice were reinfected with 100 larvae. On days 20 and 21 after reinfection the numbers of $N$. dubius eggs per gm (epg) of mouse faeces from individual mice were determined using the McMaster technique (Roberts and O'Sullivan, 1950). Faeces for epg counts were collected between 0900 and 1100 hours only.

In total, 975 mice from the parental, filial and backcross families were examined in this experiment. At each infection of batches of these mice, 10 female Quackenbush (Q) mice were also infected with 100 larvae as a control for the infectivity of the parasite stock, which can be influenced by environmental parameters (Kerboeuf, 1978). These $Q$ mice were killed 21 days after infection and the numbers of adult $N$. dubius that they harboured were counted. The means of these numbers recovered from each control group of Q mice were used to standardise the faecal epg counts from the experimental mice to overcome any variations in the infectivity of the parasite larvae, using Sitepu and Dobson's (1982) formula.

\section{RESULTS}

The results for the filial and backcross progeny are presented in two ways. Firstly, mean values for faecal $N$. dubius epg counts for the $\mathrm{F}_{1}, \mathrm{~F}_{2}$, backcross to high $(\mathrm{BCH})$ and backcross to low (BCL) immune responder mice were compared with the parental lines to examine a role for additive effects and dominance in this trait. Secondly, mean values for $F_{1}\left(F_{1} H\right.$ and $\left.F_{1} L\right)$ and backcross ( $\mathrm{BC} 1, \mathrm{BC} 2 \ldots \mathrm{BC} 8)$ progeny, with reference to the sex of each parent, were compared with values for the parental $\mathrm{H}$ and $\mathrm{L}$ mice to examine the influence of the sex of parental genotypes in this trait.

Fig. 1 summarises all the epg data. Fig. 2 and table 2 are based on the same mice as in fig. 1 and 


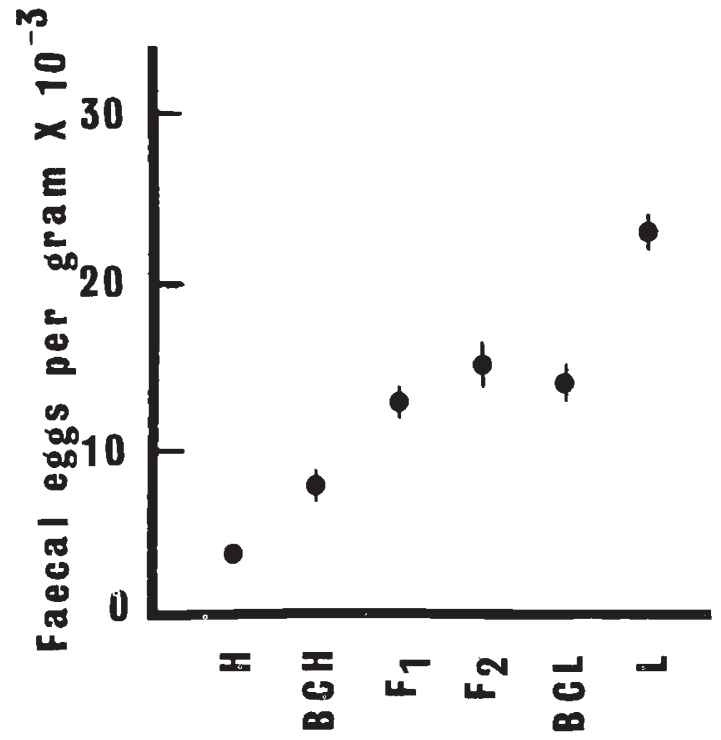

Mouse genotype

Figure 1 Mean \pm S.E. faecal Nematospiroides dubius epg counts from mice selectively reared for high $(\mathrm{H})$ and low (L) immunity to infection and from filial and backcross families derived from them. table 1 , but the results have been broken down into finer categories.

\section{$H, L, F_{1}, F_{2}, B C H$ and $B C L$ progeny}

Mean values for these families are given in fig. 1 . The mean value for the $F_{1}$ mice was distant from both the $\mathrm{H}$ and $\mathrm{L}$ values, but was closer to the $\mathrm{H}$ than to the $\mathrm{L}$ mean. The $\mathrm{F}_{2}$ mean was equidistant between the $\mathrm{H}$ and $\mathrm{L}$ progeny means. The $F_{1}$ and $\mathrm{F}_{2}$ mean epg values were not statistically different from each other, but the variance of the $F_{2}$ epg values was greater than that of the $F_{1}$ 's-307 and 180 respectively. The mean for the $\mathrm{BCH}$ progeny was midway between the $\mathrm{H}$ and $\mathrm{F}_{1}$ means, whereas the mean $B C L$ was not significantly different from the $F_{1}$ mean.

All the $\mathrm{H}$ mice used to breed the mice described in this experiment had expressed the phenotype " 0 epg" after challenge $N$. dubius infection. Of $200 \mathrm{H}$ progeny, 71 (or 36 per cent) expressed the " 0 epg" phenotype of their parents. Of $128 \mathrm{~L}$ progeny, 39 (29 per cent) expressed faecal epg values ">40,000 epg", which was the phenotype of the $\mathrm{L}$ parents used for breeding. Of the $58 \mathrm{~F}_{2}$ progeny, one showed the " 0 epg" phenotype and 3 showed the ">40,000 epg" phenotype (table 1).

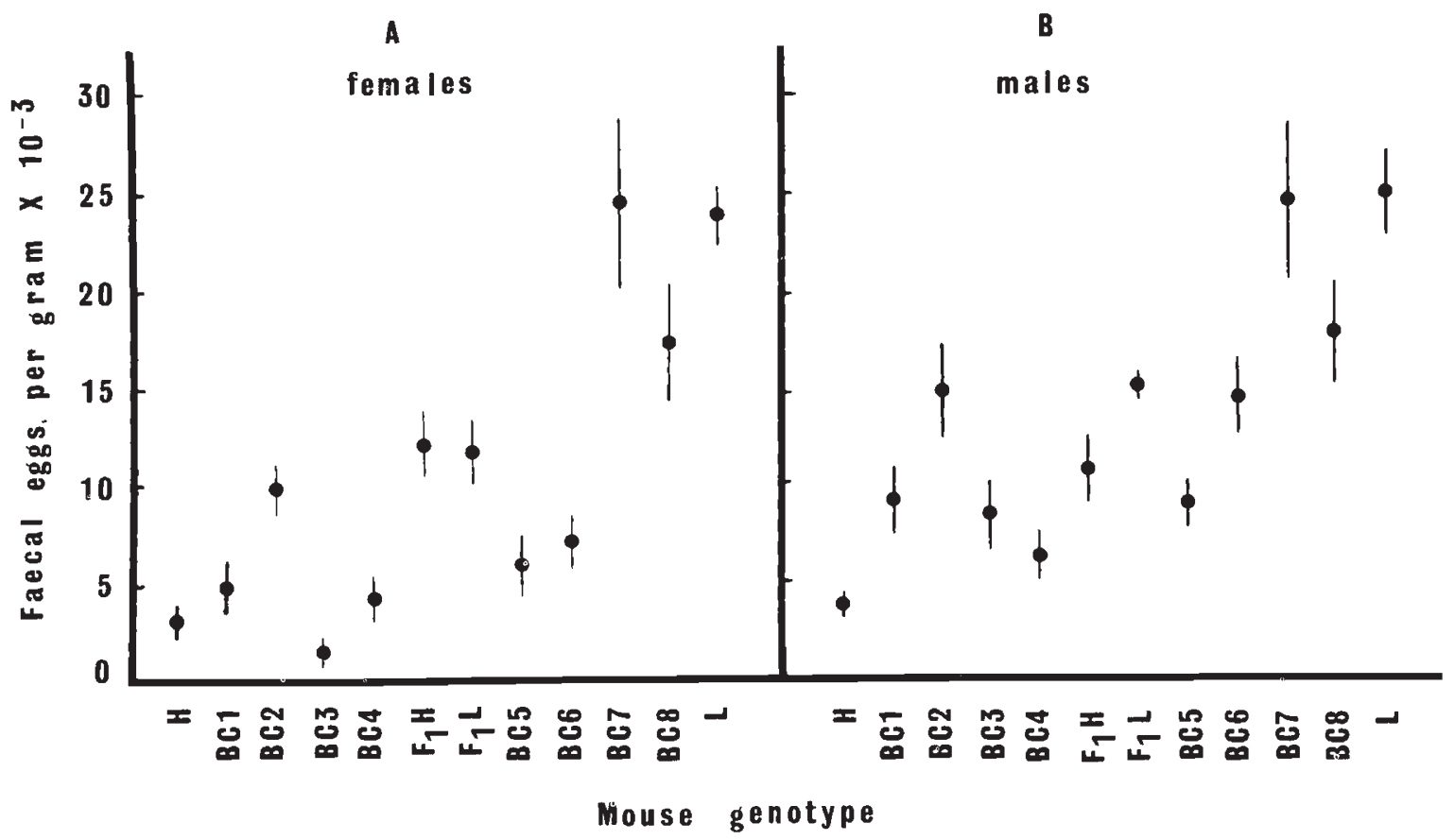

Figure 2 Mean $t$ S.E. faecal Nematospiroides dubius epg counts from mice selectively reared for high (H) and low (L) immunity to infection, and from $F_{1}, F_{2}$ and backcross families derived from them. 
Table 1 Percentages of families of mice displaying the parental H ("0 epg") and L (">40,000 epg") phenotypes

\begin{tabular}{|c|c|c|c|}
\hline \multicolumn{4}{|c|}{ Percentage of progeny exhibiting parental phenotype } \\
\hline Family & $\begin{array}{l}\text { "0 epg" } \\
\text { phenotype }\end{array}$ & $\begin{array}{l}\text { " }>40,000 \text { epg" } \\
\text { phenotype }\end{array}$ & $\begin{array}{l}\text { Number of } \\
\text { mice }\end{array}$ \\
\hline $\mathrm{H}$ & 36 & 0 & 200 \\
\hline $\mathrm{BCH}$ & 20 & 1 & 215 \\
\hline$F_{1}$ & 3 & 4 & 179 \\
\hline $\mathrm{F}_{2}$ & 2 & 5 & 58 \\
\hline $\mathrm{BCL}$ & 4 & 8 & 195 \\
\hline $\mathbf{L}$ & 0 & 29 & 128 \\
\hline
\end{tabular}

Table 2 Percentages of families of mice displaying the parental H ("0 epg") and L "(>40,000 epg)" phenotypes

\begin{tabular}{|c|c|c|c|}
\hline \multicolumn{4}{|c|}{ Percentage of progeny exhibiting parental phenotype } \\
\hline Family & $\begin{array}{l}\text { "0 epg" } \\
\text { phenotype }\end{array}$ & $\begin{array}{l}\text { " } 40,000 \text { epg" } \\
\text { phenotype }\end{array}$ & $\begin{array}{l}\text { Number of } \\
\text { mice* }\end{array}$ \\
\hline $\mathrm{H}$ & 36 & 0 & 200 \\
\hline $\mathrm{BC} 1$ & 12 & 0 & 51 \\
\hline BC2 & 4 & 1 & 72 \\
\hline $\mathrm{BC} 3$ & 53 & 0 & 36 \\
\hline BC4 & 27 & 2 & 56 \\
\hline $\mathrm{F}_{1} \mathrm{H}$ & 1 & 4 & 92 \\
\hline $\mathrm{F}_{1} \mathrm{~L}$ & 5 & 2 & 87 \\
\hline $\mathrm{BC} 5$ & 12 & 0 & 49 \\
\hline BC6 & 3 & 4 & 68 \\
\hline $\mathrm{BC} 7$ & 0 & 18 & 40 \\
\hline BC8 & 0 & 13 & 38 \\
\hline L & 0 & 29 & 128 \\
\hline
\end{tabular}

* Similar numbers of females and males within each family.

\section{$H, L, F_{1} H, F_{1} L$ and $B C 1$ through $B C 8$ progeny}

The mean values for each sex in each of these families are compared in fig. 2. Several trends appeared. A comparison of fig. 2(a) with fig. 2(b) showed that the level of immunity was generally higher i.e., lower faecal $N$. dubius epg, in females than males. The mean faecal epg value was significantly lower in females than in males in the $\mathrm{BC} 2$ and $\mathrm{BC} 3$ families ( $t$-values $2 \cdot 81$ and $2 \cdot 03$, $P<0.01$ and $P<0.05$, respectively) and was lower, though not significantly so, in 8 of the other 10 families. In the other two families, $\mathrm{F}_{1} \mathrm{H}$ and $\mathrm{BC} 7$, the faecal egg count was not significantly different between males and females within each family, although the epg values were lower for males than females in both these families.

The BC2 family was notable because the BC2 mean epg was higher than that of each of the three other backcross to $\mathrm{H}$ families (male mice, $t$-values $1.69,1.74$ and $2.69, P$ N.S.-not significant, N.S. and $<0.05$; female mice, $t$ values $2 \cdot 08,2 \cdot 33$ and $2.69, P<0.05$ all cases). The female $\mathrm{F}_{1} \mathrm{H}$ and $\mathrm{F}_{1} \mathrm{~L}$ showed similar mean epg values whereas the $F_{1} L$ male progeny showed a mean epg value that was 40 per cent higher than, though not significantly different from, the mean for male $F_{1} \mathrm{H}$ mice. In the backcross to $\mathrm{L}$ families, the $\mathrm{BC} 5$ and $\mathrm{BC} 6$ mice were more immune than the $\mathrm{BC} 7$ and $\mathrm{BC} 8$ mice. (All $t$-comparisons significantly different at $P<$ 0.05 to $<0.01$ except male $\mathrm{BC} 6$ versus male $\mathrm{BC} 8$ where $P$ N.S.) Indeed, the $\mathrm{BC} 5$ and $\mathrm{BC} 6$ more closely resembled the backcross to $\mathrm{H}$ families than they resembled $\mathrm{BC} 7, \mathrm{BC} 8$ or $\mathrm{L}$ mice. Mice in $\mathrm{BC} 7$ and $\mathrm{BC} 8$ showed poor immunity to reinfection with $N$. dubius, as did the L progeny.

Table 2 lists the percentage of each of the $F_{1}$ and backcross families exhibiting the parental phenotypes " 0 epg" or " $>40,000$ epg". These data emphasise the same trends in immunity seen in fig. 2. In particular, the $\mathrm{BC} 7$ and $\mathrm{BC} 8$ mice appear most like the $\mathrm{L}$ progeny, much more so than do the $\mathrm{BC} 5$ and $\mathrm{BC} 6$ progeny.

\section{Analysis for sex-linkage}

We designed these series of matings to produce $\mathrm{F}_{1} \mathrm{H}, \mathrm{F}_{1} \mathrm{~L}$ and $\mathrm{BC} 1$ through $\mathrm{BC} 8$ families in order to determine whether sex-linked genes were involved in the inheritance of immunity in mice to challenge infection with $N$. dubius. According to Mather and Jinks (1971), the diagnostic properties of sex-linkage are (a) a difference between reciprocal crosses in the $F_{1}$ generation which is confined to males, and (b) a difference between reciprocal crosses in the two backcrosses, in both sexes, but a difference between the two reciprocal crosses using the inbred line as the female parent which is confined to the female progeny.

When we made these comparisons, we found no significant difference between the epg means for male $F_{1} H$ and male $F_{1} L$. Concerning the reciprocal crosses in the two backcrosses, only two of the eight comparisons showed significant differences. These were $\mathrm{BC} 1$ vs. $\mathrm{BC} 2$, females, and BC5 vs. BC6, males ( $t$-values, $2 \cdot 15$ and $2 \cdot 78, P<$ 0.05 and $<0.01)$, respectively. Furthermore, when we compared the two reciprocal crosses using the inbred line ( $\mathrm{H}$ or $\mathrm{L}$ ) as the female parent, we indeed found significant differences between families in female progeny means ( $\mathrm{BC} 2$ vs. $\mathrm{BC} 4$, females, $t=2 \cdot 08, P<0.05$; BC5 vs. BC7, females, $t=3 \cdot 86$, $P<0.01$ ), but there were also significant differences between corresponding male families ( $\mathrm{BC} 2 \mathrm{vs}$. BC4, males, $t=2 \cdot 66, P<0 \cdot 01$; BC5 vs. BC 7 , males, $t=5 \cdot 74, P<0 \cdot 01)$.

In summary, there were numerous inconsistencies with the results described here in relation to a positive diagnosis of sex-linkage in this trait. 


\section{DISCUSSION}

Selectively reared outbred mice rather than syngeneic laboratory strains were used in this experiment because the $\mathrm{H}$ and $\mathrm{L}$ mice were bred for high and low immunity to a natural infectionsyngeneic strains do differ in their responses to reinfection with $N$. dubius (Prowse, Mitchell, Ey and Jenkin, 1979) but these differences to this and other diseases in such strains occur by chance. The extremes in infection shown by the $\mathrm{H}$ and $\mathrm{L}$ lines resulted from changes in frequencies of genes responsible specifically, and perhaps only, for resistance to challenge infection with $N$. dubius.

There appear to us to be two reasonable ways to analyse these progeny data. One is to compare the frequencies in the inbred, filial and backcross progenies of mice displaying the extreme phenotypes of the parent lines, viz., "0 epg" or ">40,000 epg". The levels of infection in the H and $L$ progeny showed that only 36 per cent and 29 per cent, respectively, displayed the extreme phenotypes of resistance and susceptibility of the parental line breeders, which suggests that neither of the parental lines was yet homozygous by generation 9 . However, these proportions may have been influenced by environmental effects and are complicated by possible genetic heterogeneity in the parasite population. Responses from the $F_{1}, F_{2}$, and backcrosses suggested quantitative rather than qualitative inheritance-the $F_{1}$ progeny mean epg, for instance, was different from the mean for either parent line. The $F_{2}$ progeny were more varied in their response to infection than the $F_{1}$ mice, perhaps resulting from the segregation of several allelic pairs and the formation of many new genetic combinations. The presence of one in $58 \mathrm{~F}_{2}$ progeny with " 0 epg" and $3 \mathrm{~F}_{2}$ progeny in 58 with ">40,000" suggested that at least 2 or 3 genes were segregating. Three allelic pairs produce a frequency of 1 in 64 for each parental phenotype among the $F_{2}$ progeny, whereas 2 allelic pairs produce a frequency of 1 in 16 . The proportions of extreme phenotypes observed among the backcross progeny also support an additive mode of inheritance for the trait because 1 in 16 (17 per cent) or 1 in 4 ( 25 per cent) of the $\mathrm{BCH}$ and the $\mathrm{BCL}$ progeny would be expected to resemble the parental phenotype if 3 or 2 pairs controlled the trait; the $\mathrm{BCH}$ and $\mathrm{BCL}$ progeny were observed to approach these proportions $(20$ per cent and 8 per cent respectively).

We consider that another way to interpret these data involves analysis using the mean epg values for the inbred progeny of the parent $\mathrm{H}$ and $\mathrm{L}$ lines rather than using the epg score of the $\mathrm{H}$ and $\mathrm{L}$ mice used to breed them i.e., 4000 and 24,200 epg, instead of " 0 epg" and ">40,000 epg", $\mathrm{H}$ and L mice, respectively. Accordingly, it seems plausible to postulate that the $\mathrm{L}$ progeny expressed the minimal effect of immunity, observed as 24,200 epg (fig. 1), by an unknown number of genes. The expression of resistance by the $\mathrm{H}$ progeny, observed as $4000 \mathrm{epg}$, would then represent contributions from other genetic factors. The range of protective immunity expressed by the filial and backcross progeny was contained in a phenotypic value of $20,200 \mathrm{epg}$ (i.e., 24,200-4000). When this value is attributed to the additive effect of three pairs of genes, for instance, each allele would contribute $3500 \mathrm{epg}$. $F_{1}$ mice, which would inherit three alleles from each of $\mathrm{H}$ and $\mathrm{L}$ parents would display immunity midway between the $\mathrm{H}$ and $\mathrm{L}$ progeny values. This was close to the observed result, though the $F_{1}$ mean was somewhat closer to the $\mathrm{H}$ than the $\mathrm{L}$ mean, which in turn indicated partial dominance for high immune responsiveness. Similarly, the action of two rather than three genes would nearly satisfy the observed result for the $F_{1}$ mice.

No role for sex-linked genes was found in this trait, although female mice were more resistant to $N$. dubius reinfection than male mice in two families. That females are more resistant than males to infection with $N$. dubius has been noted previously by Dobson (1961) who showed that testosterone depresses the resistance of female mice to infection. Accordingly, we speculate that the action of genes involved in this trait in mice can be regulated by sex hormones.

Most examples of genetic control of immunity to helminth infections in mammals are quantitative (see Wakelin, 1978; Mitchell, 1979), though examples of qualitative control are known. In particular, Wassom, De Witt and Grundmann (1974) showed that immunity in deer mice to infection with Hymenolepis citelli was controlled by a single dominant allele, as is the immune expulsion of Trichinella spiralis from the laboratory mouse (Bell, Adams and Ogden, 1984). In contrast, Correa-Oliveira (1985) demonstrated that vaccineinduced resistance in mice to Schistosoma mansoni was inherited as a single recessive allele. Wakelin (1975) carried out a backcross trial using mice selected for their immune response to the enteric nematode Trichuris muris, and found ratios of progeny expressing the parent phenotypes which indicated the involvement of 3 genes but which expressed dominance rather than addition for protective immunity against that infection. The 
analysis of Wakelin's (1975) results was simplified because immunity to $T$. muris is an all-or-nothing event i.e., qualitative rather than quantitative genetic inheritance as is seen with $N$. dubius in the $\mathrm{H}$ and $\mathrm{L}$ mice (Sitepu, et al., 1986).

In summary, the mechanism of inheritance of immunity in these mice to challenge infection with $N$. dubius is complex, but it exhibits partial dominance for high immune responsiveness, and additive effects. Complexity arises from the influence of host immunity on a variety of parasite biological functions including establishment, growth and reproduction (Brindley and Dobson, 1982, 1983; Sitepu et al., 1986) and, furthermore, parasites also have genetic mechanisms which enable them to respond to changes in host resistance (Day, 1974).

Acknowledgements This work was supported by the Australian Research Grants Scheme, the Australian Development Assistance Bureau, and a University of Queensland Postdoctoral Fellowship held by P.J.B.

\section{REFERENCES}

BELL, R. G., ADAMS, L. S. AND OGDEN, R. W. 1984. A single gene determines rapid expulsion of Trichinella spiralis in mice. Infection and Imminity 45, 273-275.

BENACERRAF, B. AND McDEVITT, H. O. 1972. Histocompatibility-linked immune response genes. Science, 175, 273-279.

BIOZZI, G., STIFFEL, C., MOUTON, D., BOUTHILLIER, Y. AND DECREUSEFOND, C. 1971. Genetic regulation of the function of antibody producing cells, Amos, B. (ed.), In Progress in Immunology. Academic Press, New York, pp. 529-545.

BRINDLEY, P. J. AND DOBSON, C. 1982. Nematospiroides dubius in mice selected for liability to infection: modification of parasite biology through host selection. International Journal for Parasitology, 12, 573-578.

BRINDLEY, P. J. AND DOBSON, C. 1983. Genetic control of liability to infection with Nematospiroides dubius in mice: direct and correlated responses to selection of mice for faecal parasite egg count. Parasitology, 87, 113-127.

BRYANT, V. 1973. The life cycle of Nematospiroides dubius, Baylis, 1926 (Nematoda: Heligmosomidae). Journal of Helminthology, 47, 263-268.

CORREA-OLIVEIRA, R. 1985. Genetic analysis of defects in the immune response of inbred mice to an attenuated vaccine against Schistosoma mansoni. Ph.D. Thesis, Johns Hopkins University.

DAY, P. R. 1974. Genetics of Host-Parasite Interaction, W. H. Freeman and Co., San Francisco.

DOBSON, C. 1961. Certain aspects of the host parasite relationship of Nematospiroides dubius (Baylis) I. Resistance of male and female mice to experimental infections. Parasitology, 51, 173-179.
DOBSON, C. AND OWEN, M. E. 1977. Influence of serial passage on the infectivity and immunogenicity of Nematospiroides dubius in mice. International Journal for Parasitology, 7, 463-466.

FALCONER, D. S. 1981. Introduction to Quantitative Genetics. 2nd edition. Longman, London.

KLEIN, J., JURETIC, A., BAXEVANIS, C. AND NAGZ, Z. A. 1981. The traditional and new version of the mouse $\mathrm{H}-2$ complex. Nature, 291, 455-460.

KERBOEUF, D. 1978. The effects of time and temperature of storage on the infectivity of third stage larvae of Heligmosomoides polygyrus (Nematospiroides dubius). 1. Effects on development to the adult stage. Annales de Recherches Veterinaires, 9, 153-159.

MATHER, K. AND JINKS, J. L. 1971. Biometrical Genetics. The Study of Continuous Variation. Cornell University Press, New York.

MITCHELL, G. F. 1979. Responses to infection with metazoan and protozoan parasites in mice. Advances in Immunology, $28,451-484$.

PROWSE, S. J., MITCHELL, G. F., EY, P. L. AND JENKIN, C. R. 1979. The development of resistance in different inbred strains of mice to infection with Nematospiroides dubius. Parasite Immunology, 1, 277-288.

ROBERTS, F. H. S. AND O'SUllivaN, P. J. 1950. Methods for egg counts and larval cultures for strongyles infecting the gastro-intestinal tract of cattle. Australian Journal of Agricultural Research, 1, 99-102.

SHER, A. AND SCOTT, P. A. 1982. Genetic factors influencing the interaction of parasites with the immune system. Clinics in Immunology and Allergy, 2, 489-510.

SITEPU, P., BRINDLEY, P. J. AND DOBSON, C. 1986. Nematospiroides dubius: direct and correlated responses to selection for high and low immune responsiveness in mice. Experimental Parasitology, 61, 57-64.

SITEPU, P. AND DOBSON, C. 1982. Genetic control of resistance to infection with Nematospiroides dubius in mice: selection of high- and low-immune response populations of mice. Parasitology, 85, 73-84.

SKAMENE, E., KONGSHAVN, P. A. L. AND LANDY, M. 1980. Genetic Control of Natural Resistance to Infection and Malignancy. Academic Press, New York.

VADAS, M. A. 1980. Parasite immunity and the major histocompatibility complex. Immunogenetics, 11, 215-223.

WAKELIN, D. 1975. Genetic control of immune response to parasites: selection for responsiveness and non-responsiveness to Trichuris muris in random bred strains of mice. Parasitology, 71, 377-384.

WAKELIN, D. 1978. Genetic control of susceptibility and resistance to parasitic infection. Advances in Parasitology, 16, 219-308.

WAKELIN, D. 1984. Evasion of the immune response: survival within low responder individuals of the host population. Parasitology, 88, 639-657.

WASSOM, D. L., DAVID, C. S. AND GLEICH, G. J. 1979. Genes within the major histocompatibility complex influence susceptibility to Trichinella spiralis in the mouse. Immunogenetics, 9, 491-496.

WASSOM, D. L., DE WITT, C. W. AND GRUNDMANN, A. W. 1974. Immunity to Hymenolepis citelli by Peromyscus manicu. latus; genetic control and ecological implications. Journal of Parasitology, 60, 47-52. 